\title{
PENGARUH KEPEMIMPINAN, KEMATANGAN PEGAWAI DAN LINGKUNGAN KERJA TERHADAP KINERJA PEGAWAI DINAS PENDIDIKAN KABUPATEN BATU BARA
}

\author{
${ }^{1}$ Irwansyah, ${ }^{2}$ Robianti Siregar, ${ }^{3}$ Trisna Tiktawati, ${ }^{4}$ Rahmawati Sukra, ${ }^{5}$ Jan Putra Siadari \\ $1,2,3,4,5$ Universitas Islam Sumatera Utara \\ 1irwansyah.mm@gmail.com, ${ }^{2}$ robianti.srg@gmail.com, ${ }^{3}$ trisna.tiktawati@gmail.com, ${ }_{4}$ rahmawati.sukra@gmail.com, \\ 5janputra.siadari@gmail.com
}

\begin{abstract}
Problem of this study it is influence of leadership on performance. It is influence of employees maturity on performance. It is influence of work environment on performance. It is influence leadership, employees maturity and work environment on performance. The purpose of this study to determine and analyze the effect of leadership on performance. Determine and analyze the effect of employees maturity on performance. Determine and analyze the effect of work environment on performance. Determine and analyze the effect of leadership, employees maturity and work environment on performance. Sample in the study is 38 employees. Data analysis techniques used in this study is descriptive analyze and multiple linear regression analysis. The results of the study indicate leadership variable has a positive and significant effect on performance. Employees maturity variable has a positive and significant effect on performance. Work environment variable has a positive and significant effect on performance. Leadership, employees maturity and work environment variable has a positive and significant effect on performance.
\end{abstract}

Keywords: Leadership, Maturity, Environment, performance.

ABSTRAK : Rumusan masalah dalam penelitian ini adalah apakah ada pengaruh kepemimpinan terhadap kinerja. Apakah ada pengaruh kematangan pegawai terhadap kinerja. Apakah ada pengaruh lingkungan kerja terhadap kinerja. Apakah ada pengaruh kepemimpinan, kematangan pegawai, dan lingkungan kerja terhadap kinerja.Tujuan penelitian ini adalah untuk mengetahui dan menganalisis pengaruh kepemimpinan terhadap kinerja. Untuk mengetahui dan menganalisis pengaruh kematangan pegawai terhadap kinerja. Untuk mengetahui dan menganalisis pengaruh lingkungan kerja terhadap kinerja. Untuk mengetahui dan menganalisis pengaruh kepemimpinan, kematangan pegawai, dan lingkungan kerja terhadap kinerja.. Sampel dalam penelitian ini berjumlah 38 orang pegawai. Teknik analisis data yang digunakan dalam penelitian ini adalah analisis deskriptif dan analisis regresi linier berganda. Hasil penelitian ini menjelaskan bahwa variabel kepemimpinan berpengaruh positif dan signifikan terhadap kinerja. Variabel kematangan pegawai berpengaruh positif dan signifikan terhadap kinerja. Variabel lingkungan kerja berpengaruh positif dan signifikan terhadap kinerja. Variabel kepemimpinan, kematangan pegawai, dan lingkungan kerja berpengaruh positif dan signifikan terhadap kinerja pegawai.

Kata kunci : Kepemimpinan, Kematangan, Lingkungan, Kinerja

\section{Pendahuluan}

Pegawai Dinas Pendidikan Kabupaten

Batu Bara merupakan salah satu sumber daya organisasi yang mempunyai nilai prakarsa dan memiliki peran penting dalam pemberdayaan sumber daya lainnya dalam organisasi. Sistem pengelolaan Sumber Daya Manusia (SDM) yang tepat merupakan kunci keberhasilan organisasi untuk mencapai tujuannya. Oleh karena itu, agar tujuan dan sasaran organisasi dapat dicapai, perlu adanya perhatian yang lebih dari organisasi terhadap upaya-upaya dalam meningkatkan kinerja pegawai.

Kinerja pegawai merupakan hasil proses yang kompleks, baik berasal dari diri pribadi pegawai (internal factor) maupun upaya strategis dari organisasi. Menurut pendapat Colquitt at.al (2009:273), kinerja adalah nilai 
dari seperangkat perilaku pegawai yang berkontribusi secara positif dan negatif untuk mencapai tujuan organisasi. Kinerja memiliki 3 (tiga) dimensi yaitu perilaku tugas, perilaku moral dan perilaku menantang. Perilaku tugas adalah tingkah laku pegawai yang terlibat secara langsung dalam mentransformasikan sumber organisasi dalam kebajikan, pelayanan atau produksi organisasi. Perilaku tugas meliputi tugas rutin dan tugas dalam pembaharuan. Perilaku moral adalah aktivitas dalam bentuk kesukarelaan dari pegawai ada reward atau tidak ada reward akan tetapi tetap memberikan kontribusi pada organisasi guna memperbaiki kualitas secara keseluruhan di tempat kerja.

Dari pendapat ahli tersebut di atas dan berlandaskan pada studi empirikal peneliti mencoba melihat permasalahan tentang kinerja pegawai di Dinas Pendidikan Kabupaten Batu Bara yang terlihat masih belum optimal. Hal ini dapat terlihat pada system pelayanan yang belum optimal ditandai dengan surat menyurat yang agak lambat prosesnya dan sistem birokrasi yang masih berbelit-belit terhadap pelayanan birokrasi.

Variabel pertama yang mempengaruhi kinerja pegawai Dinas Pendidikan Kabupaten Batu Bara adalah kepemimpinan. Pemimpin berperan penting dalam menciptakan iklim kerja yang baik, solid, dan harmonis bagi pegawai guna menumbuhkan semangat kerja sehingga dapat meningkatkan kinerja serta dapat menciptakan kualitas pekerjaan sesuai dengan yang diharapkan. Suwatno \& Priansa (2011:156) mengemukakan bahwa pemimpin harus dapat menjalin kerja sama yang baik dengan bawahan untuk mencapai tujuan organisasi. Dengan cara seperti itu, maka pemimpin akan banyak mendapat bantuan berupa pikiran, semangat, dan tenaga dari bawahan yang akan menimbulkan semangat bersama dan rasa persatuan, sehingga akan memudahkan proses pendelegasian dan pemecahan masalah yang semuanya dilakukan untuk memajukan organisasi. Penelitian dari Fauzi (2013) menyatakan bahwa faktor kepemimpinan berpengaruh terhadap kinerja. Hal ini sesuai dengan pengertian kepemimpinan dari Siagian (2013:124) bahwa kepemimpinan adalah kemampuan dan keterampilan seseorang yang menduduki jabatan sebagai pemimpin satuan kerja untuk mempengaruhi prilaku orang lain terutama bawahannya untuk berfikir dan untuk bertindak sedemikian rupa sehingga melalui prilaku yang positif ia memberikan sumbangsih yang nyata dalam pencapaian tujuan organisasi. Untuk mencapai tujuan bersama, pegawai yang ada di Dinas Pendidikan Kabupaten Batu Bara perlu membina kebersamaan dengan mengikuti pengendalian dari pemimpinnya. Dengan pengendalian tersebut, perbedaan keinginan, kehendak, kemauan, perasaan, kebutuhan dan lain-lain dipertemukan untuk digerakkan kearah yang sama. Dengan demikian berarti perbedaan individual dimanfaatkan untuk mencapai tujuan yang sama sebagai kegiatan kepemimpinan atasan di Dinas Pendidikan Kabupaten Batu Bara. Berdasarkan pengamatan yang penulis lakukan terhadap 5 orang pegawai, penulis menemukan masih ada pegawai yang merasakan bahwa dibadan tempat mereka bekerja para pegawai diperlakukan secara tidak adil (kognitif), dan menunjukkan sikap mengkritisasi segala bentuk kebijakan atasan serta perencanaan kerja dari atasan belum sepenuhnya dapat terserap oleh bawahan. Kondisi-kondisi tersebut menggambarkan atau merupakan fenomena terjadinya masalah kepemimpinan di Dinas Pendidikan Kabupaten Batu Bara.

Variabel kedua yang mempengaruhi kinerja pegawai Dinas Pendidikan Kabupaten Batu Bara adalah kematangan. Hasil penelitian dari Adlina (2014) dan Sri Isworo Ediningsih (2009) menyatakan bahwa kematangan seorang pegawai berdampak signifikan terhadap kinerjanya. Teori dari Suryana (2009:88) kematangan adalah kemampuan individu untuk dapat mengontrol dan mengendalikan diri terhadap pekerjaan yang menjadi tanggung jawabnya. Kematangan mempunyai ciri-ciri penerimaan diri, baik individu yang memiliki kematangan akan dapat menerima kondisi fisik maupun psikisnya, baik secara pribadi maupun secara sosial, dan kemampuan dalam mengontrol dorongan yang muncul dalam diri individu untuk melakukan sesuatu yang bertentangan dengan nilai-nilai yang berlaku akan dapat dikendalikan dan diorganisasikan ke arah yang baik. Fenomena tentang kematangan pegawai Dinas Pendidikan Kabupaten Batu Bara diantaranya pegawai kurang memahami visi, misi, sasaran dan tujuan organisasi, sebagian pegawai kurang bersikap sabar jika ada masalah dalam pekerjaannya

Variabel ketiga yang mempengaruhi kinerja pegawai adalah lingkungan kerja. Hasil penelitian yang dilakukan oleh Tri Widari 
(2016) menunjukkan bahwa lingkungan kerja berpengaruh signifikan terhadap kinerja pegawai, begitu juga hasil penelitian dari Dewa (2015) menyatakan bahwa lingkungan kerja berpengaruh terhadap kinerja. Berdasarkan temuan penelitian tersebut maka penelitian ini bertujuan untuk menganalisis dan menguji kembali pengaruh lingkungan kerja terhadap kinerja pegawai Dinas Pendidikan Kabupaten Batu Bara. Berdasarkan survei awal fenomena tentang lingkungan kerja diantaranya penerangan pada ruang kerja masih kurang terang dan kondisi ruang kerja tertata kurang rapi, yang mana hal ini disebabkan oleh kondisi ruang kerja yang kurang luas.

\subsection{Batasan Masalah}

Agar permasalahan yang dikaji terarah maka permasalahan dibatasi sebagai berikut. Penelitian ini hanya membahas faktor kepemimpinan, kematangan pegawai, lingkungan kerja dan kinerja pegawai Dinas Pendidikan Kabupaten Batu Bara.

\subsection{Hioptesis}

Berdasarkan pada studi empiris dan kerangka konseptual di atas, maka dapat diajukan hipotesis penelitian ini sebagai berikut

1) Kepemimpinan berpengaruh positif dan sgnifikan terhadap kinerja pegawai Dinas Pendidikan Kabupaten Batu Bara.

2) Kematangan pegawai berpengaruh positif dan sgnifikan terhadap kinerja pegawai Dinas Pendidikan Kabupaten Batu Bara.

3) Lingkungan kerja berpengaruh positif dan sgnifikan terhadap kinerja pegawai Dinas Pendidikan Kabupaten Batu Bara.

4) Kepemimpinan, kematangan pegawai dan lingkungan kerja berpengaruh positif dan sgnifikan terhadap kinerja pegawai Dinas Pendidikan Kabupaten Batu Bara.

\subsection{Tujuan Penelitian}

Tujuan penelitian ini adalah :

1) Untuk mengetahui dan menganalisis pengaruh kepemimpinan terhadap kinerja pegawai Dinas Pendidikan Kabupaten Batu Bara.

2) Untuk mengetahui dan menganalisis pengaruh kematangan pegawai terhadap kinerja pegawai Dinas Pendidikan Kabupaten Batu Bara.

3) Untuk mengetahui dan menganalisis pengaruh lingkungan kerja terhadap kinerja pegawai Dinas Pendidikan Kabupaten Batu Bara.

4) Untuk mengetahui dan menganalisis pengaruh kepemimpinan, kematangan pegawaim dan lingkungan kerja terhadap kinerja pegawai Dinas Pendidikan Kabupaten Batu Bara.

\section{Metode Penelitian}

\subsection{Populasi}

Populasi merupakan subjek penelitian dimana individu yang akan dikenai perilaku atau dapat dikatakan sebagai keseluruhan objek penelitian yang akan diteliti. Maka yang menjadi populasi dalam penelitian ini adalah seluruh pegawai Dinas Pendidikan Kabupaten Batu Bara yang berjumlah 38 orang, dimana kepala dinas dan peneliti tidak disertakan sebagai populasi.

\subsection{Sampel}

Menurut Arikunto (2011 78), teknik sampling merupakan teknik pengambilan sampel, sedangkan sampel adalah sebagian dari jumlah dan karanteristik yang dimiliki oleh populasi. Dengan menggunakan teknik penarikan sampel yaitu total sampling atau metode sensus, maka sampel dalam penelitian ini berjumlah 38 orang pegawai Dinas Pendidikan Kabupaten Batu Bara.

Tabel 1. Kerangka sampel berdasarkan bagian

\begin{tabular}{|c|l|c|}
\hline No & \multicolumn{1}{|c|}{ Keterangan } & $\begin{array}{c}\text { Jumlah } \\
\text { (Orang) }\end{array}$ \\
\hline 1 & Sekretariat & 15 \\
\hline 2 & Bidang Pembinaan PAUD dan Non Formal & 3 \\
\hline 3 & Bidang Pembinaan Pendidikan Dasar & 7 \\
\hline 4 & Bidang Kebudayaan & 8 \\
\hline 5 & Bidang Pembinaan Ketenagaan & 5 \\
\hline \multicolumn{2}{|c|}{ Jumlah } & 38 \\
\hline
\end{tabular}

Sumber : Dinas Pendidikan Kabupaten Batu Bara, 2020 


\subsection{Uji Normalitas}

Pengujian normalitas data penelitian adalah untuk menguji apakah dalam model statistik variabel-variabel penelitian berdistribusi normal atau tidak normal. Model regresi yang tinggi adalah memiliki distribusi normal atau mendekati normal. Untuk menguji apakah distribusi data normal atau tidak, salah satunya dengan menggunakan metode gambar normal Probabilitas Plots digunakan untuk menyimpulkan apakah model analisis memenuhi asumsi normal, dengan penyebaran data di sekitar garis diagonal dan mengikuti arah garis diagonal maka data tersebut mememenuhi asumsi normal dalam model analisis, yang dapat dilihat pada gambar dibawah ini :

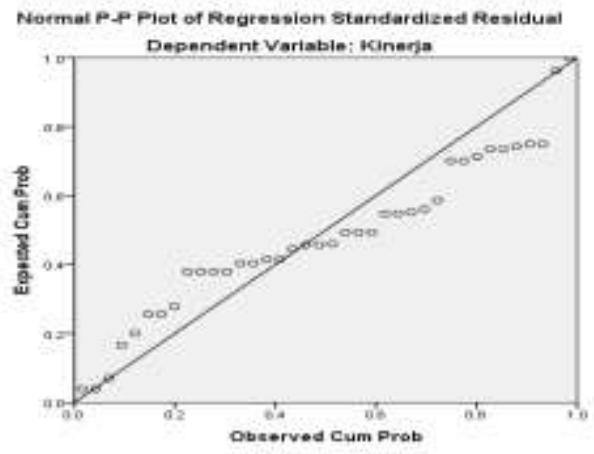

Gambar 1. Uji asumsi normalitas

Dari Gambar 1, diatas dapat dijelaskan bahwa penyebaran data berada di sekitar garis diagonal dan mengikuti arah garis diagonal, maka dapat ditarik kesimpulan data tersebut mememenuhi asumsi normal atau berdistribusi normal. Selanjutnya uji normalitas data juga dapat menggunakan uji Kolmogorov-Smirnov Test, dengan hasil sebagai berikut.

Tabel 2 One-Sample Kolmogorov-Smirnov Test

\begin{tabular}{|c|c|c|}
\hline & & $\begin{array}{l}\text { Unstandardized } \\
\text { Residual }\end{array}$ \\
\hline $\mathrm{N}$ & & 38 \\
\hline Normal Parameterca,b & Mean & 43.7105 \\
\hline 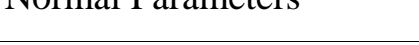 & Std. Deviation & 3.01266 \\
\hline & Absolute & .171 \\
\hline Most Extreme Differences & Positive & .154 \\
\hline & Negative & -.171 \\
\hline Kolmogorov-Smirnov Z & & 1.055 \\
\hline Asymp. Sig. (2-tailed) & & .216 \\
\hline
\end{tabular}

Sumber : Hasil pengolahan data, 2020

Berdasarkan Tabel 2, diatas diketahui signifikansi sebesar 0,216. Nilai signifikansi ini lebih besar dari 0,05 , sehingga dapat disimpulkan bahwa data yang diuji berdistribusi normal.

\subsection{Uji Multikolinearitas}

Multikolinieritas berarti adanya hubungan yang kuat diantara beberapa atau semua variabel bebas pada model regresi. Jika terdapat multikolinieritas maka koefisien regresi

Tabel 3. Uji asumsi multikolinieritas pengaruh kepemimpinan, kematangan pegawai dan lingkungan kerja terhadap kinerja

\begin{tabular}{|l|c|c|}
\hline \multirow{2}{*}{\multicolumn{1}{|c|}{ Variabel }} & \multicolumn{2}{c|}{ Collinearity Statistics } \\
\cline { 2 - 3 } & Tolerance & VIF \\
\hline Kompetensi & .871 & 1.147 \\
\hline Disiplin & .864 & 1.157 \\
\hline Lingkungan kerja & .760 & 1.315 \\
\hline a Dependent Variable: Kinerja
\end{tabular}

menjadi tidak tentu, tingkat kesalahannya menjadi sangat besar dan biasanya ditandai dengan koefisien determinasi yang sangat besar tetapi pada pengujian parsial koefisien regresi, tidak ada atau pun kalau ada sangat sedikit sekali koefisien regresi yang signifikan. Pada penelitian ini digunakan nilai Variance Inflantion Factorrs (VIF) sebagai indikator ada tidaknya multikolinearitas di antara variabel bebas. 
Dari Tabel 3, dapat dijelaskan bahwa nilai Variance Inflantion Factorrs (VIF) yang diperoleh dalam penelitian ini sebesar 1,147; 1,$157 ; 1,315$; dimana nilai Variance Inflantion Factorrs (VIF) dari ketiga varibel bebas lebih kecil dari 10 dan dapat disimpulkan tidak terdapat multikolinieritas diantara ketiga variabel bebas dalam penelitian ini.

\subsection{Uji Autokorelasi}

Tabel 4. Model summary ${ }^{\mathrm{b}}$ pengaruh kepemimpinan, kematangan pegawai dan lingkungan kerja terhadap kinerja

\begin{tabular}{|c|c|c|c|c|c|c|}
\hline \multirow[b]{2}{*}{ Model } & \multicolumn{5}{|c|}{ Change Statistics } & \multirow{2}{*}{$\begin{array}{l}\text { Durbin- } \\
\text { Watson }\end{array}$} \\
\hline & $\begin{array}{l}\text { R Square } \\
\text { Change }\end{array}$ & F Change & df1 & df2 & $\begin{array}{c}\text { Sig. F } \\
\text { Change }\end{array}$ & \\
\hline 1 & .630 & 19.336 & 3 & 34 & .000 & 2.148 \\
\hline
\end{tabular}

Berdasarkan Tabel 4 di atas diperoleh nilai statistik Durbin-Watson (DW) sebesar 2.148, nilai tersebut berada pada kisaran 1,65 < DW < 2,35 maka dapat disimpulkan tidak terdapat autokorelasi pada model regresi dalam penelitian ini.

\subsection{Uji Heteroskedastisitas}

Uji heteroskedastisitas bertujuan untuk menguji apakah dalam model regresi terjadi ketidaksamaan variance dari residual satu pengamatan ke pengamatan yang lainnya. Gejala variance yang tidak sama ini disebut dengan heteroskedastisitas, sedangkan adanya gejala residual yang sama dari satu pengamatan ke pengamatan lain disebut dengan homokedastisitas. Menurut Sugiyono (2014:158) pengertian dari heteroskedastisitas adalah dimana dalam model regresi tejadi ketidaksamaan varian dari residual pada suatu pengamatan ke pengamatan yang lain. Model regresi yang baik adalah tidak terjadi heteroskedastisitas. Berbagai macam uji heteroskedastisitas yaitu dengan uji glejser, melihat pola titik-titik pada scatterplots regresi, atau uji koefisien korelasi spearman's.

Uji heteroskedastisitas dapat dilakukan dengan menggunakan grafik scatterplot antara nilai variabel terikat (ZSPRED) dengan residualnya (SRESID), dimana sumbu $X$ adalah yang diprediksi dan sumbu $\mathrm{Y}$ adalah residual. Dasar pengambilan keputusan yang dapat diambil adalah sebagai berikut :

a. Jika pola tertentu seperti titik-titik yang ada membentuk suatu pola yang teratur
Autokorelasi sebagai suatu korelasi antara nilai variabel dengan nilai variabel yang sama satu atau lebih. Menurut Cornelius (2005: 212), kisaran nilai uji autokorelasi yang dilakukan dalam pengujian Durbin Watson (DW) sebagai berikut :

$1.65<\mathrm{DW}<2.35$ tidak terjadi autokorelasi 1.21. $<$ DW $<1.65$ atau $2.35<\mathrm{DW}<2.79$ tidak dapat disimpulkan.

DW $<1.21$ atau DW $>2.79$ terjadi autokorelasi. 
lingkungan kerja terhadap kinerja pegawai Berdasarkan hasil pengolahan data diperoleh Dinas Pendidikan Kabupaten Batu Bara. hasil sebagai berikut :

Tabel 5. Coefficients ${ }^{\mathrm{a}}$ pengaruh kepemimpinan, kematangan pegawai dan lingkungan kerja terhadap kinerja

\begin{tabular}{|c|c|c|c|c|c|c|}
\hline \multirow{2}{*}{\multicolumn{2}{|c|}{ Model }} & \multicolumn{2}{|c|}{$\begin{array}{l}\text { Unstandardized } \\
\text { Coefficients }\end{array}$} & \multirow{3}{*}{$\begin{array}{c}\text { Standardized } \\
\text { Coefficients } \\
\text { Beta }\end{array}$} & \multirow{2}{*}{$\mathrm{t}$} & \multirow{2}{*}{ Sig. } \\
\hline & & B & Std. Error & & & \\
\hline \multirow[t]{4}{*}{1} & (Constant) & 5.541 & 5.066 & & 1.094 & .282 \\
\hline & Kepemimpinan & .164 & .080 & .229 & 2.046 & .049 \\
\hline & Kematangan & .251 & .078 & .358 & 3.196 & .003 \\
\hline & Lingkungan kerja & .483 & .120 & .481 & 4.025 & .000 \\
\hline
\end{tabular}

Berdasarkan Tabel 5, out put SPSS "Coefficients" diatas, persamaan regresi linier berganda adalah sebagai berikut :

$$
Y=5.541+0_{0.164 X_{1}}+0.251 X_{2}+
$$

Berdasarkan persamaan regresi linier berganda ini, maka dapat dijelaskan maksud dari persamaan di atas :

1) Nilai konstanta dari persamaan regresi dari penelitian ini sebesar 5.541, hal ini menyatakan bahwa nilai variabel kinerja pegawai Dinas Pendidikan Kabupaten Batu Bara sebesar 5.541.

2) Koefisien regresi untuk variabel kepemimpinan sebesar 0.164, hal ini menjelaskan bahwa variabel kepemimpinan berpengaruh positif terhadap kinerja pegawai Dinas Pendidikan Kabupaten Batu Bara

3) Koefisien regresi untuk variabel kematangan pegawai sebesar 0.251 , hal ini menjelaskan bahwa variabel kematangan pegawai berpengaruh positif terhadap kinerja pegawai Dinas Pendidikan Kabupaten Batu Bara.

4) Koefisien regresi untuk variabel lingkungan kerja sebesar 0.483, hal ini menjelaskan bahwa variabel lingkungan kerja berpengaruh positif terhadap kinerja pegawai Dinas Pendidikan Kabupaten Batu Bara
Dari persamaan di atas dapat ditarik kesimpulan bahwa model regresi ini sudah layak dan benar, dan dapat dijelaskan bahwa variabel kepemimpinan, kematangan pegawai dan lingkungan kerja berpengaruh positif dan signifikan terhadap kinerja pegawai Dinas Pendidikan Kabupaten Batu Bara.

\subsection{Pengaruh Kepemimpinan Terhadap Kinerja Pegawai Dinas Pendidikan Kabupaten Batu Bara.}

Untuk mengetahui pengaruh kompetensi terhadap kinerja pegawai Dinas Pendidikan Kabupaten Batu Bara digunakan uji-t, dengan ketentuan sebagai berkut :

1) Jika nilai $t_{\text {hitung }}>t_{\text {tabel }}$ dan nilai probabilitas $(p)<$ tingkat signifikansi $5 \%(\alpha=0,05)$ maka hipotesis penelitian $\left(\mathrm{H}_{1}\right)$ diterima dan $\mathrm{H}_{0}$ ditolak, berarti ada pengaruh signifikan antara kepemimpinan terhadap kinerja.

2) Jika nilai $t_{\text {hitung }}<t_{\text {tabel }}$ dan nilai probabilitas (p) > tingkat signifikansi 5\% $(\alpha=0,05)$ maka hipotesis penelitian $\left(\mathrm{H}_{1}\right)$ ditolak dan $\mathrm{H}_{0}$ diterima, berarti tidak ada pengaruh signifikan antara kepemimpinan terhadap kinerja.

Penelitian ini menggunakan taraf signifikansi $(\alpha \quad 0,05)$ dan Derajat Kebebasan (DK) dengan ketentuan DK $=\mathrm{n}-2$, atau $38-2$ $=36$. Dengan ketentuan tersebut, diperoleh nilai $\mathrm{t}_{\text {tabel }}$ sebesar 2,028.

Tabel. 6. Coeficients ${ }^{\mathrm{a}}$ pengaruh kepemimpinan terhadap kinerja

\begin{tabular}{|l|l|r|r|r|r|r|}
\hline \multirow{2}{*}{ Model } & \multicolumn{2}{|c|}{$\begin{array}{c}\text { Unstandardized } \\
\text { Coefficients }\end{array}$} & $\begin{array}{c}\text { Standardized } \\
\text { Coefficients } \\
\text { Beta }\end{array}$ & t & \multirow{2}{*}{ Sig. } \\
\cline { 3 - 4 } \multicolumn{2}{|c|}{} & \multicolumn{1}{|c|}{ B } & Std. Error & . & \\
\hline 1 & (Constant) & 5.541 & 5.066 & & 1.094 & .282 \\
\hline & Kepemimpinan & .164 & .080 & .229 & 2.046 & .049 \\
\hline
\end{tabular}

a Dependent Variable : Kinerja

Hasil pengolahan data, 2020 
Berdasarkan Tabel 6, out put SPSS "Coeficients" diatas diketahui nilai $t_{\text {hitung }}$ variabel kompetensi sebesar 2.046. Karena nilai $t_{\text {hitung }}>t_{\text {tabel }}(2.046>2,013)$ dan nilai signifikasi $0,049<0,05$, sehingga $\mathrm{H}_{0}$ ditolak dan $\mathrm{H}_{1}$ diterima. Artinya hipotesis yang diajukan dalam penelitian ini diterima yaitu variabel kepemimpinan secara partial berpengaruh positif dan signifikan terhadap kinerja pegawai Dinas Pendidikan Kabupaten Batu Bara. Hasil penelitian ini menjelaskan bahwa semakin baik kepemimpinan memberikan perhatian ke bawahan maka semakin tinggi kinerja pegawai Dinas Pendidikan Kabupaten Batu Bara.

\subsection{Pengaruh Kematangan Pegawai \\ Terhadap Kinerja Pegawai Dinas \\ Pendidikan Kabupaten Batu Bara.}

Untuk mengetahui pengaruh kematangan pegawai terhadap kinerja pegawai Dinas
Pendidikan Kabupaten Batu Bara digunakan uji-t, dengan ketentuan sebagai berkut :

1) Jika nilai $t_{\text {hitung }}>t_{\text {tabel }}$ dan nilai probabilitas (p) $<$ tingkat signifikansi 5\% $(\alpha=0,05)$ maka hipotesis penelitian $\left(\mathrm{H}_{1}\right)$ diterima dan $\mathrm{H}_{0}$ ditolak, berarti ada pengaruh signifikan antara kematangan pegawai terhadap kinerja.

2) Jika nilai $t_{\text {hitung }}<t_{\text {tabel }}$ dan nilai probabilitas (p) > tingkat signifikansi 5\% $(\alpha=0,05)$ maka hipotesis penelitian $\left(\mathrm{H}_{1}\right)$ ditolak dan $\mathrm{H}_{0}$ diterima, berarti tidak ada pengaruh signifikan antara kematangan pegawai terhadap kinerja.

Penelitian ini menggunakan taraf signifikansi $(\alpha \quad 0,05)$ dan Derajat Kebebasan (DK) dengan ketentuan DK $=\mathrm{n}-2$, atau $38-2$ $=36$. Dengan ketentuan tersebut, diperoleh nilai $\mathrm{t}_{\text {tabel }}$ sebesar 2,028.

Tabel. 7. Coeficients ${ }^{\mathrm{a}}$ pengaruh kematangan pegawai terhadap kinerja

\begin{tabular}{|c|c|c|c|c|c|c|}
\hline \multirow{2}{*}{\multicolumn{2}{|c|}{ Model }} & \multicolumn{2}{|c|}{$\begin{array}{c}\text { Unstandardized } \\
\text { Coefficients }\end{array}$} & \multirow{3}{*}{$\begin{array}{l}\text { Standardized } \\
\text { Coefficients } \\
\text { Beta }\end{array}$} & \multirow{2}{*}{$\mathrm{t}$} & \multirow{2}{*}{ Sig. } \\
\hline & & B & Std. Error & & & \\
\hline \multirow[t]{2}{*}{1} & (Constant) & 5.541 & 5.066 & & 1.094 & .282 \\
\hline & $\begin{array}{l}\text { Kematangan } \\
\text { pegawai }\end{array}$ & .251 & .078 & .358 & 3.196 & .003 \\
\hline
\end{tabular}

Berdasarkan Tabel 7, out put SPSS "Coeficients" diatas diketahui nilai $\mathrm{t}_{\text {hitung }}$ variabel disiplin sebesar 3.196. Karena nilai $t_{\text {hitung }}>t_{\text {tabel }}(3.196>2,013)$ dan nilai signifikasi $0,003<0,05$, sehingga $\mathrm{H}_{0}$ ditolak dan $\mathrm{H}_{1}$ diterima. Artinya hipotesis yang diajukan dalam penelitian ini diterima yaitu variabel kematangan pegawai secara partial berpengaruh positif dan signifikan terhadap kinerja pegawai Dinas Pendidikan Kabupaten Batu Bara. Hasil penelitian ini menjelaskan bahwa semakin baik kematangan pegawai maka semakin tinggi kinerja pegawai Dinas Pendidikan Kabupaten Batu Bara.

\subsection{Pengaruh Lingkungan Kerja Terhadap Kinerja Pegawai Dinas Pendidikan Kabupaten Batu Bara.}

Untuk mengetahui pengaruh lingkungan kerja terhadap kinerja pegawai Dinas
Pendidikan Kabupaten Batu Bara digunakan uji-t, dengan ketentuan sebagai berkut :

1) Jika nilai $t_{\text {hitung }}>t_{\text {tabel }}$ dan nilai probabilitas (p) $<$ tingkat signifikansi 5\% $(\alpha=0,05)$ maka hipotesis penelitian $\left(\mathrm{H}_{1}\right)$ diterima dan $\mathrm{H}_{0}$ ditolak, berarti ada pengaruh signifikan antara lingkungan kerja terhadap kinerja.

2) Jika nilai $t_{\text {hitung }}<t_{\text {tabel }}$ dan nilai probabilitas (p) > tingkat signifikansi 5\% $(\alpha=0,05)$ maka hipotesis penelitian $\left(\mathrm{H}_{1}\right)$ ditolak dan $\mathrm{H}_{0}$ diterima, berarti tidak ada pengaruh signifikan antara lingkungan kerja terhadap kinerja.

Penelitian ini menggunakan taraf signifikansi $(\alpha \quad 0,05)$ dan Derajat Kebebasan (DK) dengan ketentuan DK $=\mathrm{n}-2$, atau $38-2$ $=36$. Dengan ketentuan tersebut, diperoleh nilai $\mathrm{t}_{\text {tabel }}$ sebesar 2,028. 
Tabel. 8. Coeficients ${ }^{\mathrm{a}}$ pengaruh lingkungan kerja terhadap kinerja

\begin{tabular}{|l|l|r|r|r|r|r|}
\hline \multirow{2}{*}{ Model } & \multicolumn{2}{|c|}{$\begin{array}{c}\text { Unstandardized } \\
\text { Coefficients }\end{array}$} & $\begin{array}{c}\text { Standardized } \\
\text { Coefficients } \\
\text { Beta }\end{array}$ & $\mathrm{t}$ & \multirow{2}{*}{ Sig. } \\
\cline { 3 - 4 } & \multicolumn{1}{|c|}{ B } & Std. Error & & & \\
\hline 1 & (Constant) & 5.541 & 5.066 & & 1.094 & .282 \\
\hline & Lingkungan kerja & .483 & .120 & .481 & 4.025 & .000 \\
\hline
\end{tabular}

a Dependent Variable : Kinerja

Hasil pengolahan data, 2020

Berdasarkan Tabel 8, out put SPSS "Coeficients" diatas diketahui nilai $\mathrm{t}_{\text {hitung }}$ variabel lingkungan kerja sebesar 4.025. Karena nilai $\mathrm{t}_{\text {hitung }}>\mathrm{t}_{\text {tabel }}(4.025>2,013)$ dan nilai signifikasi $0,000<0,05$, sehingga $\mathrm{H}_{0}$ ditolak dan $\mathrm{H}_{1}$ diterima. Artinya hipotesis yang diajukan dalam penelitian ini diterima yaitu variabel lingkungan kerja secara partial berpengaruh positif dan signifikan terhadap kinerja pegawai Dinas Pendidikan Kabupaten Batu Bara. Hasil penelitian ini menjelaskan bahwa semakin baik lingkungan kerja maka semakin tinggi kinerja pegawai Dinas Pendidikan Kabupaten Batu Bara.

\subsection{Pengaruh Kepemimpinan, Kematangan Pegawai dan Lingkungan Kerja Terhadap Kinerja Pegawai Dinas Pendidikan Kabupaten Batu Bara.}

Untuk mengetahui pengaruh kepemimpinan, kematangan pegawai dan lingkungan kerja terhadap kinerja pegawai
Dinas Pendidikan Kabupaten Batu Bara digunakan uji-F, dengan ketentuan sebagai berkut :

1) Jika nilai $F_{\text {hitung }}>F_{\text {tabel }}$ dan nilai probabilitas (p) $<$ tingkat signifikansi $5 \%(\alpha=0,05)$ maka hipotesis penelitian $\left(\mathrm{H}_{1}\right)$ diterima dan $\mathrm{H}_{0}$ ditolak, berarti ada pengaruh signifikan antara kepemimpinan, kematangan pegawai dan lingkungan kerja terhadap kinerja.

2) Jika nilai $F_{\text {hitung }}<F_{\text {tabel }}$ dan nilai probabilitas (p) > tingkat signifikansi 5\% $(\alpha=0,05)$ maka hipotesis penelitian $\left(\mathrm{H}_{1}\right)$ ditolak dan $\mathrm{H}_{0}$ diterima, berarti tidak ada pengaruh signifikan antara kepemimpinan, kematangan pegawai dan lingkungan kerja terhadap kinerja.

Penelitian ini menggunakan taraf signifikansi $(\alpha \quad 0,05)$ dan Derajat Kebebasan (DK) dengan ketentuan numerator : jumlah variabel -1 atau $4-1=3$, dan jumlah sampel dikurang 4 atau $38-4=34$. Dengan ketentuan tersebut, diperoleh nilai $\mathrm{F}_{\text {tabel }}$ sebesar 2,66.

Tabel 9. Anova ${ }^{\mathrm{b}}$ pengaruh kepemimpinan, kematangan pegawai dan lingkungan kerja terhadap kinerja

\begin{tabular}{|l|l|r|r|r|r|c|}
\hline \multirow{2}{*}{ Model } & & $\begin{array}{c}\text { Sum of } \\
\text { Squares }\end{array}$ & \multicolumn{1}{c|}{ df } & $\begin{array}{c}\text { Mean } \\
\text { Square }\end{array}$ & \multicolumn{1}{c|}{ F } & Sig. \\
\hline \multirow{4}{*}{1} & Regression & 211.719 & 3 & 70.573 & 19.336 & $.000^{\mathrm{a}}$ \\
\cline { 2 - 7 } & Residual & 124.097 & 34 & 3.650 & & \\
\cline { 2 - 7 } & Total & 335.816 & 37 & & & \\
\hline
\end{tabular}

Dependent Variable: Kinerja

Hasil pengolahan data, 2020

Berdasarkan Tabel 9, out put SPSS "Anova" diatas diketahui nilai $\mathrm{F}_{\text {hitung }}>\mathrm{F}_{\text {tabel }}$ $(19.336>2,66)$ dan nilai signifikasi $0,000<$ 0,05, sehingga $\mathrm{H}_{0}$ ditolak dan $\mathrm{H}_{1}$ diterima. Artinya variabel kepemimpinan, kematangan pegawai dan lingkungan kerja secara simultan atau bersama-sama berpengaruh positif dan signifikan terhadap kinerja pegawai Dinas Pendidikan Kabupaten Batu Bara.

\subsection{Uji Determinan}

Uji determinan adalah untuk melihat seberapa besar pengaruh variabel kepemimpinan, kematangan pegawai dan lingkungan kerja terhadap kinerja pegawai Dinas Pendidikan Kabupaten Batu Bara secara simultan, maka dapat dilihat dari hasil perhitungan dalam model summary, khususnya angka $R_{\text {Square }}$ dibawah ini 
Tabel 10. Model summary ${ }^{\mathrm{b}}$ pengaruh kepemimpinan, kematangan pegawai dan lingkungan kerja terhadap kinerja

\begin{tabular}{|l|c|r|r|r|}
\hline Model & R & R Square & $\begin{array}{c}\text { Adjusted R } \\
\text { Square }\end{array}$ & \multicolumn{1}{c|}{ Std. Error of the Estimate } \\
\hline 1 & $.794^{\mathrm{a}}$ & .630 & .598 & 1.91047 \\
\hline
\end{tabular}

Dependent Variable: Kinerja

Hasil pengolahan data, 2020

Berdasarkan Tabel 10, out put SPSS "Model summary" diatas, diperoleh nilai $\mathrm{R}_{\text {Square }}$ $\left(r^{2}\right)$ adalah 0,630. Nilai tersebut mempunyai maksud bahwa pengaruh variabel kepemimpinan, kematangan pegawai dan lingkungan kerja terhadap kinerja pegawai Dinas Pendidikan Kabupaten Batu Bara sebesar $63 \%$, sedangkan sisanya sebesar $37 \%(100 \%$ $63 \%$ ) dipengaruhi oleh faktor-faktor lain yang tidak diteliti. Dengan kata lain variabilitas kinerja pegawai Dinas Pendidikan Kabupaten Batu Bara dapat diterangkan oleh variabel kepemimpinan, kematangan pegawai dan lingkungan kerja sebesar 63\%, sedangkan sisanya sebesar $37 \%$ disebabkan oleh variabelvariabel lain diluar model penelitian ini.

\section{Kesimpulan}

Berdasarkan pada analisis dan evaluasi data pada bab sebelumnya, maka dapat ditarik kesimpulan sebagai berikut :

1) Variabel kepemimpinan berpengaruh positif dan signifikan terhadap kinerja pegawai Dinas Pendidikan Kabupaten Batu Bara dengan nilai $t_{\text {hitung }}>t_{\text {tabel }}(2.046>2,013)$ dan nilai signifikasi $0,049<0,05$.

2) Variabel kematangan pegawai berpengaruh positif dan signifikan terhadap kinerja pegawai Dinas Pendidikan Kabupaten Batu Bara dengan nilai $t_{\text {hitung }}>t_{\text {tabel }}(3.196>$ $2,013)$ dan nilai signifikasi $0,003<0,05$.

3) Variabel lingkungan kerja berpengaruh positif dan signifikan terhadap kinerja pegawai Dinas Pendidikan Kabupaten Batu Bara dengan nilai $t_{\text {hitung }}>t_{\text {tabel }}(4.025>$ $2,013)$ dan nilai signifikasi $0,000<0,05$.

4) Variabel kepemimpinan, kematangan pegawai dan lingkungan kerja berpengaruh positif dan signifikan terhadap kinerja pegawai Dinas Pendidikan Kabupaten Batu Bara dengan nilai $F_{\text {hitung }}>F_{\text {tabel }}(19.336>$ 2,66) dan nilai signifikasi $0,000<0,05$.

5) Pengaruh variabel kepemimpinan, kematangan pegawai dan lingkungan kerja terhadap kinerja pegawai Dinas Pendidikan Kabupaten Batu Bara sebesar 63\%, sedangkan sisanya sebesar 37\% dipengaruhi oleh faktor-faktor lain yang tidak diteliti.

\section{DAFTAR PUSTAKA}

Adlina Yulianti Dyah Suryadiningrum (2014), Pengaruh Kematangan Karyawan Terhadap Kinerja Karyawan Dengan Komitmen Organisasional Sebagai Variabel Moderating (Studi Pada Karyawan Himalaya Garment Kota Malang), Jurnal administrasi Bisnis, Vol.1 No. 1.

Andari (2016), Pengaruh Kepemimpinan Dan Lingkungan Kerja Terhadap Kinerja Pegawai Dinas Koperasi Dan UMKM Provinsi Banten, Jurnal Sains Manajemen, Volume.2 No.2 Juni 2016

Arikunto, Suharsismi. (2011). Prosedur Penelitian Suatu Pendekatan Praktek. Jakarta: Rineka Cipta.

Colquitt, J. A., LePine, J. A., and Wesson., (2009) Organizational Behavior: Improving Performance and Commitment in the Workplace, New York, McGraw Hill, pp. 37

Cross, T.M dan Lynch. R.R. (2011). Peniliaian dan Evaluasi Kinerja: Konsep dan Praktik. Jakarta. Penerbit Ghalia Indonesia

Dessler, Gary. (2013). Manajemen Sumber Daya Manusia (Jilid I). Jakarta : Indeks.

Dewa Putu Meles Arta (2015), Pengaruh Motivasi dan Lingkungan Kerja Terhadap Kinerja PNS Pada KPP Bea dan Cukai Tipe Madya Pabean Ngurah Rai Kabupaten Badung, Juima,Vol, 5 No. 1 Maret 2015

Fauzi, A. (2013). Pengaruh Kepemimpinan, Kecerdasan Individuonal dan Motivasi terhadap Kinerja Guru di SMA. Jurnal Manajemen Pendidikan Vol 1, No 1

Gibson, James L., Ivancevich, John M., Donnely, James H., and Konopaske (2009) Organizations: Behavior, Structure, Processes,New York, McGraw Hill

Goleman, D. (2014). Emotional Entellegent. PT. Gramedia Pustaka Utama, Jakarta 
Hasibuan, Malayu S. P. (2013). Manajemen Sumber Daya Manusia. Edisi Revisi Jakarta: PT. Bumi Aksara.

Mangkunegara, Anwar, Prabu. (2009). Evaluasi Kinerja SDM, Cetakan 4, Bandung : Refika Aditama

Mangkuprawira, Sjafri. (2014). Manajemen Sumber Daya Manusia Strategik. Cetakan ketiga, Penerbit Ghalia Indonesia

Murphy, S. E., and Pirozzolo, F. J., (2011) Multi Journal ple Intelligences and Leadership, New Jersey, Lawrence Erlbaum

Ridwan. (2013). Skala Pengukuran VariabelVariabel Bandung : Alfabeta

Robbins S.P \& Judge,T.A. 2013. Perilaku Organisasi. Buku 1 Edisi 12. Terjemahan Diana Angelica. Penerbit Salemba Empat. Jakarta.

Robbins, Stephen P. (2006). Perilaku Organisasi. Edisi kesepuluh. Jakarta: Indeks Kelompok Gramedia.

Rush, Michael dan Althoff, Phillip. (2009). Pengantar Sosiologi Politik. Jakarta: PT. Raja Grafindo Persada.

Samsudin, Sadili. (2009). Manajemen Sumber Daya Manusia. Bandung: CV. Pustaka Setia.

Sedarmayanti. (2014). Good Governance (Kepemerintahan Yang Baik), Bandung : Mandar Maju

Sekaran, U., dan Bougie (2010), Research Methods for Busines. A Skill Building Approach. Fifth Edition. A John Wiley and Sons, Ltd, Publication.

Siagian, Sondang. (2013). Manajemen Sumber Daya Manusia (cetakan 15). Jakarta: Bumi Aksara

Sink, R dan Tuttle, J.K. (1989). Evaluasi Kinerja. Jakarta: Indeks Kelompok Gramedia.

Smithson, Janet., Suzan Lewis (2013). Is job insecurity changing the psychological contract. Personnel Review ,29(6):1-15

Sri Isworo Ediningsih, Wisnalmawati Wisnalmawati (2009), Pengaruh Kematangan Karyawan Dengan Gaya Kepemimpinan Situasional Pengusaha Perempuan Sebagai Variabel Moderating Terhadap Kinerja Karyawan, Jurnal Analisis Bisnis Ekonomi, Vol. 7 No. 1

Sugiyono. (2009). Metode Penelitian Kuantitatif dan Kualitatif dan R \& D. Bandung : Alfabeta
Suryana Sumantri (2013). Perilaku Organisasi. Bandung: Universitas Padjadjaran

Sutrisno, Edy (2014). Manajemen Sumber Daya Manusia, Kencana Prenada Media Group Jakarta

Thoha, Miftah. (2001). Birokrasi Indonesia Dalam Era Globalisasi, Pusdiklat Pegawai Depdiknas, Sawangan, Bogor.

Terry George dan Rue, Leslie W alih bahasa Sadeli (2011), Dasar-Dasar Manajemen, Cetakan Ketujuh Bumi Aksara Jakarta.

Triton PB (2015), Paradigma Baru Manajemen Sumber Daya Manusia, Tugu Yogyakarta. (2006), SPSS 12.00 Terapan Riset Statistik Parametrik, Andi Yogyakarta.

Tri Widari (2016), Pengaruh Disiplin dan Lingkungan Kerja Terhadap Kinerja Pegawai BKD Daerah Istimewa Jogjakarta, Tesis UNY

Yukl, G. (2013). Kepemimpinan Dalam Organisasi.Edisi Indonesia (kelima). Cetakan kedua. Penerbit PT Indeks, Jakarta. 